\title{
Correction to: Parental Health Spillover in Cost-Effectiveness Analysis: Evidence from Self-Harming Adolescents in England
}

\author{
Sandy Tubeuf ${ }^{1,2}$ (D) Eirini-Christina Saloniki ${ }^{3,4} \cdot$ David Cottrell $^{5}$
}

Published online: 19 February 2019

(c) The Author(s) 2019

\section{Correction to: PharmacoEconomics https://doi.org/10.1007/s40273-018-0722-6}

The Open Access license, which previously read:

Open Access This article is distributed under the terms of the Creative Commons Attribution-NonCommercial 4.0International License (http://creativecommons.org/licen ses/by-nc/4.0/), which permits any noncommercial use, distribution, and reproduction in any medium, provided you give appropriate credit to the original author(s) and the source, provide a link to the Creative Commons license, and indicate if changes were made.

Should read:

Open Access This article is distributed under the terms of the Creative Commons Attribution 4.0 International License (http://creativecommons.org/licenses/by/4.0/), which permits unrestricted use, distribution, and reproduction in any medium, provided you give appropriate credit to the original author(s) and the source, provide a link to the Creative Commons license, and indicate if changes were made.

The original article was corrected.

Open Access This article is distributed under the terms of the Creative Commons Attribution 4.0 International License (http://creativeco mmons.org/licenses/by/4.0/), which permits unrestricted use, distribution, and reproduction in any medium, provided you give appropriate credit to the original author(s) and the source, provide a link to the Creative Commons license, and indicate if changes were made.

The original article can be found online at https://doi.org/10.1007/ s40273-018-0722-6.

Sandy Tubeuf

s.tubeuf@leeds.ac.uk; sandy.tubeuf@uclouvain.be

Eirini-Christina Saloniki

e.saloniki@kent.ac.uk

David Cottrell

d.j.cottrell@leeds.ac.uk

1 Academic Unit of Health Economics, University of Leeds, Leeds LS2 9NL, UK

2 Institute of Health and Society, Université Catholique de Louvain, Louvain-La-Neuve, Belgium

3 Centre for Health Services Studies, University of Kent, Kent, UK

4 Personal Social Services Research Unit, University of Kent, Kent, UK

5 Psychological and Social Medicine, University of Leeds, Leeds, UK 